\title{
I Did Attend a First Aid Course at the Very Least (World First Aid Day Guest Comment)
}

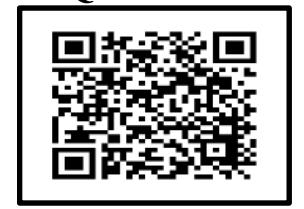

A few years ago, I read an article while scouring the internet for a presentation on first aid which reported that almost a 150000 people died of a lack of first aid in the UK - that number being as high as mortality due to cancer. ${ }^{1}$ There were though a few skeptics who claimed otherwise ${ }^{2}$, but it was enough to shock me.

At that time, I asked myself if I knew first aid and if could help save someone else's life, if it came down to it and just like the other $98 \%$ of us - I didn't have a clue (Chatterjee, 2016). ${ }^{2}$ I had a lot of questions! What am I supposed to do when I see someone choke on food? What should I do when someone is unable to breathe because of Lord knows what? What to do when someone has an accident - vehicular or otherwise? Maybe, I should just wait for EMS while the poor guy gags? Have I ever been trained in First Aid? I did not have answers to all those questions except for one - I was never trained in first aid. I had seen it on TV and overheard people dying from the lack of it but it never bothered me up until I read that newspaper article about the lack of first aid killing almost as many people as cancer.

It is a fact that accidents happen - there are no two ways about it, you probably would have been in one. Experiencing it as a bystander, an accident is such a scene which one can't look away from even if he tries, one does peek anyways. If an accident happens in the workplace, you cannot be a helpless witness because we are better than that, since simply standing there hopelessly can potentially worsen the situation. This is why it should be the duty of everyone to have at least a basic knowledge of first aid. At its most basic, first aid is the initial assistance given to a victim of injury or illness. Comprised of relatively simple techniques that can be performed with rudimentary equipment, first aid is usually carried out by a layperson until professional medical assistance arrives.
I consider myself to be good citizen and a good Samaritan who introspects and always wants to better himself so you can imagine how this was a shock to me that I had not the slightest clue about first aid. To my pleasant surprise I found there were innumerable institutions in my own vicinity (some privately owned and some government) who offered courses on first aid which were for the most part free. I feel it should be an obligation which could be mandated by the government to offer such courses at least once at offices/educational institutions; and if they were being offered already: 98\% of us would've known something about first aid. It's important to remember if you don't learn, you can fail; if you don't practice, you can fail; if you don't care, you failed. Now I can say that I cared and that I did do something about it. I did attend a first aid course at the very least.

\section{REFERENCES}

1. Lack of first aid skills endangers up to 150,00o lives. (2010, April 12). Retrieved from the guardian: https://www.theguardian.com/society/2010/apr/12/ first-aid-skills-deaths [Last Accessed $12^{\text {th }}$ July 2017]

2. Does a lack of first aid skills kill as many people as cancer? (2012). Retrieved from fullfact.org: https://fullfact.org/health/does-lack-first-aid-skillskill-many-people-cancer/ [Last Accessed 12 $^{\text {th }}$ July 2017]

Cite this article as:

Thakur K. I Did Attend a First Aid Course at the Very Least (World First Aid Day Guest Comment). Int Healthcare Res J 2018;2(6):126.

doi: 10.26440/IHRJ/02_06/192

Author Details \& Corresponding Address:

Abhay Thakur (M. Pharm)

Pushpac Complex

Sector 49-B

Chandigarh - 160047
For article enquiry/author contact details, e-mail at: manuscriptenquiry.ihrj@gmail.com 